\title{
The Case for Endothelial Preservation via Pressure-Regulated Distension in the Preparation of Autologous Saphenous Vein Conduits in Cardiac and Peripheral Bypass Operations
}

\author{
Eric S. Wise ${ }^{1 *}$ and Colleen M. Brophy ${ }^{2,3}$ \\ ${ }^{1}$ Department of Surgery, University of Maryland Medical Center, Baltimore, MD, USA, ${ }^{2}$ VA Tennessee Valley Healthcare \\ System, Vanderbilt University, Nashville, TN, USA, ${ }^{3}$ Department of Surgery, Vanderbilt University Medical Center, \\ Nashville, TN, USA
}

Keywords: vein graft preparation, endothelium, vascular, saphenous vein graft, CABG, bypass

\section{INTRODUCTION}

OPEN ACCESS

Edited by:

Patrick O. Myers,

University of Geneva, Switzerland

Reviewed by:

Pradeep Narayan,

Rabindranath Tagore International Institute of Cardiac Sciences, India

*Correspondence: Eric S. Wise ericstephenwise@gmail.com

Specialty section:

This article was submitted to Heart Surgery,

a section of the journal

Frontiers in Surgery

Received: 12 August 2016 Accepted: 12 September 2016 Published: 22 September 2016

Citation:

Wise ES and Brophy CM (2016)

The Case for Endothelial

Preservation via Pressure-Regulated

Distension in the Preparation

of Autologous Saphenous Vein Conduits in Cardiac and Peripheral

Bypass Operations.

Front. Surg. 3:54.

doi: 10.3389/fsurg.2016.00054
The human saphenous vein (HSV) remains the most common conduit for peripheral and aortocoronary bypass operations in the United States $(1,2)$, with ever improving, though suboptimal long-term patency rates. The mishandling of vein grafts during explantation, preparation, and autotransplantation is gaining attention as a source of injury portending increased short-term thrombosis as well as acceleration of neointimal formation, the most common cause of vein graft failure from 2 months to 2 years postoperatively $(3,4)$. The handling of vein grafts during the explantation has been thoughtfully addressed, as "no-touch" open harvest has emerged as an approach stressing a minimization of trauma to tissue handling. In "no-touch" harvesting, the graft is removed with a pedicle of surrounding tissue. This has been shown to maintain structural and functional integrity of all cell layers, prevent spasm (5), and improve graft patency $(6,7)$, while conferring protection from subsequent intraoperative manipulations $(8,9)$.

Nonetheless, once HSV has been fully explanted, manipulations to the conduit are routinely performed to make the anastomosis technically simpler and safer. The most well-characterized and injurious of these intraoperative manipulations is intraluminal radial distension (10). HSV is routinely cannulated and distended using a handheld syringe to infuse a solution or autologous blood, which dilates the vein. This procedure serves to disrupt any valves, increase the luminal diameter, identify leaks or injuries, prevent spasm, and ultimately, facilitate an easier anastomosis $(11,12)$. It is the opinion of the authors that this practice should be done with great care, emphasizing minimization of distension pressure using either controlled distension or a tool, such as a pressure release valve. While not conclusive, existing data strongly suggest that mitigation of distension-induced graft injury may prevent both early and delayed graft failure due to thrombosis and neointimal hyperplasia, respectively.

\section{SUMMARY OF THE LITERATURE}

Starting in the late 1970s, the practice of unregulated intraluminal distension became the target of significant research $(13,14)$. Biochemical and biomechanical effects of intraoperative distension were progressively characterized throughout the next several decades. Unregulated distension of HSV graft can exert radial pressures as great as $600-700 \mathrm{mmHg}$, far in excess of physiologic systolic blood 
pressure, which of itself is supraphysiologic to the unadapted venous wall $(11,13,15,16)$. There are myriad biochemical and biomechanical changes to the cells and extracellular matrix that occur in HSV conduit upon arterial implantation, with chronic exposure to an arterial distension pressure. However, there is a unique profile of biochemical and biomechanical changes that have been shown to occur with acute intraoperative distension, particularly involving the critical endothelial layer whose integrity is most indispensable for graft patency.

Intraoperative distension exerts a brief unidirectional force similar to laminar shear stress on the conduit. The harmful biochemical and biomechanical effects induced are decidedly different from those observed in chronically arterialized endothelial cells (14). Chiefly, distension of HSV leads to significant and pressure-dependent endothelial denudation. This was first reported in 1980, when scanning electron microscopy revealed qualitatively severe endothelial damage in monkey saphenous vein at $700 \mathrm{mmHg}$ distension, though normal morphology was observed at pressures of $300-400 \mathrm{mmHg}$ (13). While several ensuing studies over the decade demonstrated a qualitative destruction of the endothelial monolayer, Angelini and colleagues first quantified this by using stimulated prostacyclin generation of vascular tissue as a surrogate for the presence of an endothelial cell. In their formative experiment, concentrations of prostacyclin were measured in fresh and surgically prepared HSV, both spontaneously and after vortex stimulation. Prostacyclin is an endothelialderived prostaglandin, which works synergistically with nitric oxide to prevent thrombosis $(17,18)$. Angelini et al.s findings that vortex-stimulated prostacyclin generation increased in response to surgical preparation were expanded to determining that it was indeed the distension aspect of surgical preparation, particularly with pressures greater than $300 \mathrm{mmHg}$, that most contributed to impaired stimulated prostacyclin generation (19). Measuring stimulated prostacyclin as a surrogate marker, this allowed the reliable quantification of degree of de-endothelialization that would become essential in multiple future experiments (19).

Microscopic quantification of denudation has further been quantified in several modern reports. Chester and colleagues reported a significant decrement in staining for endothelial markers endothelial nitric oxide synthase (eNOS), platelet endothelial cell adhesion molecule (CD31), and von Willebrand Factor (vWF) in segments of HSV distended to $300 \mathrm{mmHg}$, though no changes were observed at $100 \mathrm{mmHg}$ distension relative to non-distended control tissue (20). Also, $300 \mathrm{mmHg}$ was a critical distension pressure for decreased expression of the endothelial marker CD34 on $\operatorname{HSV}(21,22)$. Similar results have been reported demonstrating impaired endothelial staining after full surgical manipulation, though surgical skin marking or preservation in solution could contribute to these findings (12, 23-26). Seminal work by Stigler and colleagues revealed sequentially increasing HSV endothelial denudation from median loss of $29-54 \%$ to $75-91 \%$ at respective pressures of $50,100,150$, and $300 \mathrm{mmHg}$, as determined by CD31 staining, though HSV grafts were exposed to the pressure continuously for $30 \mathrm{~min}$ (27). In a porcine model, unregulated distension of saphenous vein was recently been shown to cause significantly decreased eNOS and CD31 staining, changes fully mitigated by distension via an in-line pressure release valve that limits intraluminal pressure to a more physiologic $140 \mathrm{mmHg}$ (11).

Functional assessment of vascular endothelium is easily quantified using an organ bath. The apparatus allows for the suspension of vascular smooth muscle tissue on a force transducer (28). The addition of acetylcholine or a cholinomimetic to a submerged vascular ring can cause activation of eNOS with subsequent nitric oxide generation and release. Nitric oxide then causes a cGMP-mediated vascular smooth muscle relaxation, the degree of which can be quantified. Endothelial-dependent physiologic responses are a valuable surrogate for denudation; however, there are limitations to its interpretation. Endothelial responses may be decreased in part due of endothelial cells that are dysfunctional in their production and release of nitric oxide. Data suggesting a significant component of endothelial dysfunction were reported by Okon and colleagues in 2004; vWF staining on distended veins remained intense, despite loss of endothelial-dependent relaxation (29). Additionally, distension is known to cause mild smooth muscle necrosis, decreasing the graft's responsiveness to endothelial-derived nitric oxide $(30,31)$.

Distension has shown the ability to upregulate markers of inflammation that are governed by the activation of nuclear factor- $\kappa \mathrm{B}(\mathrm{NF}-\kappa \mathrm{B})$ and subsequent generation of the cytokine TNF-alpha $(24,32-34)$. HSV distended at $300 \mathrm{mmHg}$ for 2 min demonstrated an average of $33 \%$ endothelial denudation; however, significant upregulation of endothelial intercellular adhesion molecule (ICAM-1), vascular cell adhesion molecule (VCAM-1), and P-selectin was also observed (35). In addition to $\mathrm{NF}-\mathrm{\kappa B}$ activation, lack of nitric oxide generation may also contribute to this change (35-37). Upregulation of these cell surface adhesion molecules promotes interactions with integrins on circulating neutrophils, monocytes, and platelets with subsequent transmigration into the vessel wall, events known to be early steps in graft obstruction (35). P-selectin, in particular, is implicated in the promotion of platelet aggregation in regions of vascular injury, leading to thrombosis (38). Its downregulation in vascular endothelium represents an emerging approach in the treatment of vein graft failure (38). Additionally, increased vascular permeability has been linked to ICAM-1 expression $(33,39)$.

These findings were replicated by Khaleel and colleagues in 2012 (16). Additional endothelial markers of inflammation were also found to be upregulated as well, via immunostaining and real-time polymerase chain reaction analyses. Toll-like receptors TLR2 and TLR4 were both increased in distended HSV, in direct proportion to luminal distension pressures. The expression of these receptors too is enhanced by TNF-alpha and contributes to immune system activation in cases of pathogen-induced inflammation (40). Their expression may accelerate vein graft failure as well. Recent data suggest that TLR2 expression may promote graft failure in vascular tissue and that this may be due to its promotion of medial smooth muscle cell migration, a key event in atherogenesis and neointimal formation (40-42). A marker of acute inflammation, endothelial TLR4 upregulation was also seen in distended HSV $(16,40)$. Its contribution to neointimal formation is well-established, as TLR4-deficient mice have shown not to develop a neointima (16). However, these consequences are primarily due to TLR4 upregulation on vascular smooth 
muscle cells rather than endothelium (43). Furthermore, both endothelial TLR2 and TLR4 have been implicated in the binding of the $\beta_{2}$-glycoprotein moiety on circulating inflammatory cells, promoting thrombosis $(44,45)$.

While penetration of circulating monocytes into the vascular medial layer represents one of the inciting events of atherogenesis, subendothelial migration with lipid accumulation and formation of foam cells directly follows (46). Distension leads to increased expression of endothelial scavenger receptors SR-A and SR-B (16). Largely found on macrophages, these receptors are also found in vascular smooth muscle cells and endothelium. Ligand binding to these receptors amplified its expression and generates a positive feedback loop. Consequences of distension-induced expression and ligand binding include lipid peroxidation, endothelial dysfunction, apoptosis, and most concerningly, foam cell formation.

\section{CONCLUSION}

While only a few key offenders are summarized herein, there are a host of other adhesion molecules, toll-like receptors, and

\section{REFERENCES}

1. Alexander JH, Ferguson TB Jr, Joseph DM, Mack MJ, Wolf RK, Gibson CM, et al. The PRoject of Ex-Vivo vein graft ENgineering via Transfection IV (PREVENT IV) trial: study rationale, design, and baseline patient characteristics. Am Heart J (2005) 150(4):643-9. doi:10.1016/j.ahj.2005.05.021

2. Conte MS, Bandyk DF, Clowes AW, Moneta GL, Seely L, Lorenz TJ, et al. Results of PREVENT III: a multicenter, randomized trial of edifoligide for the prevention of vein graft failure in lower extremity bypass surgery. J Vasc Surg (2006) 43(4):742-51; discussion 751. doi:10.1016/j.jvs.2005.12.058

3. Lau GT, Lowe HC, Kritharides L. Cardiac saphenous vein bypass graft disease. Semin Vasc Med (2004) 4(2):153-9. doi:10.1055/s-2004-835373

4. Motwani JG, Topol EJ. Aortocoronary saphenous vein graft disease: pathogenesis, predisposition, and prevention. Circulation (1998) 97(9):916-31. doi:10.1161/01.CIR.97.9.916

5. Souza DS, Arbeus M, Botelho Pinheiro B, Filbey D. The no-touch technique of harvesting the saphenous vein for coronary artery bypass grafting surgery. Multimed Man Cardiothorac Surg (2009) 2009(731):mmcts.2008.003624. doi:10.1510/mmcts.2008.003624

6. Mannion JD, Marelli D, Brandt T, Stallings M, Cirks J, Dreifaldt M, et al. "No-touch" versus "endo" vein harvest: early patency on symptom-directed catheterization and harvest site complications. Innovations (Phila) (2014) 9(4):306-11. doi:10.1097/IMI.0000000000000084

7. Souza DS, Johansson B, Bojo L, Karlsson R, Geijer H, Filbey D, et al. Harvesting the saphenous vein with surrounding tissue for $C A B G$ provides long-term graft patency comparable to the left internal thoracic artery: results of a randomized longitudinal trial. J Thorac Cardiovasc Surg (2006) 132(2):373-8. doi:10.1016/j.jtcvs.2006.04.002

8. Rueda F, Souza D, Lima Rde C, Menezes A, Johansson B, Dashwood M, et al. Novel no-touch technique of harvesting the saphenous vein for coronary artery bypass grafting. Arq Bras Cardiol (2008) 90(6):356-62. doi:10.1590/ S0066-782X2008000600002

9. Sen O, Gonca S, Solakoglu S, Dalcik H, Dalcik C, Ozkara A. Comparison of conventional and no-touch techniques in harvesting saphenous vein for coronary artery bypass grafting in view of endothelial damage. Heart Surg Forum (2013) 16(4):E177-83. doi:10.1532/HSF98.20131006

10. Angelini GD, Bryan AJ, Hunter S, Newby AC. A surgical technique that preserves human saphenous vein functional integrity. Ann Thorac Surg (1992) 53(5):871-4. doi:10.1016/0003-4975(92)91455-I

11. Li FD, Eagle S, Brophy C, Hocking KM, Osgood M, Komalavilas P, et al. Pressure control during preparation of saphenous veins. JAMA Surg (2014) 149(7):655-62. doi:10.1001/jamasurg.2013.5067 scavenger receptors that are ostensibly overexpressed in distended HSV, particularly those that are also regulated by NF- $\kappa \mathrm{B}$ translocation (24). Many of these changes likely contribute to vein graft failure. There are no studies in human patients examining the influence of vein graft distension pressure on patency; however, in the authors' opinion, minimization of distension represents a simple modification to the conduit preparation process that may very well prevent graft failure, the extent to which, however, is unclear. Options exist to minimize distension, however, including pressure-regulated syringes or pressure release valves to prevent undue pressurization of the saphenous vein grafts $(25,26)$. These represent simple modifications to the vein graft preparation process that preserve functional and structural properties of the conduit endothelium, and thus, may very plausibly abrogate or retard thrombosis and neointimal hyperplasia.

\section{AUTHOR CONTRIBUTIONS}

EW contributed to research, writing, and critical revision of the manuscript. CB oversaw all aspects of the research and composition of the manuscript. All authors gave final approval.

12. Osgood MJ, Hocking KM, Voskresensky IV, Li FD, Komalavilas P, CheungFlynn J, et al. Surgical vein graft preparation promotes cellular dysfunction, oxidative stress, and intimal hyperplasia in human saphenous vein. J Vasc Surg (2014) 60(1):202-11. doi:10.1016/j.jvs.2013.06.004

13. Bonchek LI. Prevention of endothelial damage during preparation of saphenous veins for bypass grafting. J Thorac Cardiovasc Surg (1980) 79(6): 911-5.

14. Tineli RA, Viaro F, Dalio MB, Reis GS, Basseto S, Vicente WV, et al. Mechanical forces and human saphenous veins: coronary artery bypass graft implications. Rev Bras Cir Cardiovasc (2007) 22(1):87-95.

15. Angelini GD, Breckenridge IM, Butchart EG, Armistead SH, Middleton KM, Henderson AH, et al. Metabolic damage to human saphenous vein during preparation for coronary artery bypass grafting. Cardiovasc Res (1985) 19(6):326-34. doi:10.1093/cvr/19.6.326

16. Khaleel MS, Dorheim TA, Duryee MJ, Durbin HE Jr, Bussey WD, Garvin RP, et al. High-pressure distention of the saphenous vein during preparation results in increased markers of inflammation: a potential mechanism for graft failure. Ann Thorac Surg (2012) 93(2):552-8. doi:10.1016/j.athoracsur. 2011.10.035

17. Feletou M, Huang Y, Vanhoutte PM. Endothelium-mediated control of vascular tone: COX-1 and COX-2 products. Br J Pharmacol (2011) 164(3):894-912. doi:10.1111/j.1476-5381.2011.01276.x

18. Radomski MW, Palmer RM, Moncada S. The anti-aggregating properties of vascular endothelium: interactions between prostacyclin and nitric oxide. Br J Pharmacol (1987) 92(3):639-46. doi:10.1111/j.1476-5381.1987. tb11367.x

19. Angelini GD, Breckenridge IM, Psaila JV, Williams HM, Henderson AH, Newby AC. Preparation of human saphenous vein for coronary artery bypass grafting impairs its capacity to produce prostacyclin. Cardiovasc Res (1987) 21(1):28-33. doi:10.1093/cvr/21.1.28

20. Chester AH, Buttery LD, Borland JA, Springall DR, Rothery S, Severs NJ, et al. Structural, biochemical and functional effects of distending pressure in the human saphenous vein: implications for bypass grafting. Coron Artery Dis (1998) 9(2-3):143-51. doi:10.1097/00019501-199809020-00012

21. Pusztaszeri MP, Seelentag W, Bosman FT. Immunohistochemical expression of endothelial markers CD31, CD34, von Willebrand factor, and Fli-1 in normal human tissues. J Histochem Cytochem (2006) 54(4):385-95. doi:10.1369/ jhc.4A6514.2005

22. Viaro F, Carlotti CG Jr, Rodrigues AJ, Vicente WV, Bassetto S, Reis GS, et al. Endothelium dysfunction caused by acute pressure distension of human saphenous vein used for myocardial revascularization. Rev Bras Cir Cardiovasc (2007) 22(2):169-75. 
23. Eagle S, Brophy CM, Komalavilas P, Hocking K, Putumbaka G, Osgood $\mathrm{M}$, et al. Surgical skin markers impair human saphenous vein graft smooth muscle and endothelial function. Am Surg (2011) 77(7):922-8.

24. Hinokiyama K, Valen G, Tokuno S, Vedin JB, Vaage J. Vein graft harvesting induces inflammation and impairs vessel reactivity. Ann Thorac Surg (2006) 82(4):1458-64. doi:10.1016/j.athoracsur.2006.05.038

25. Wise ES, Hocking KM, Eagle S, Absi T, Komalavilas P, Cheung-Flynn J, et al. Preservation solution impacts physiologic function and cellular viability of human saphenous vein graft. Surgery (2015) 158(2):537-46. doi:10.1016/ j.surg.2015.03.036

26. Wise ES, Hocking KM, Feldman D, Komalavilas P, Cheung-Flynn J, Brophy CM. An optimized preparation technique for saphenous vein graft. Am Surg (2015) 81(7):E274-6.

27. Stigler R, Steger C, Schachner T, Holfeld J, Edlinger M, Grimm M, et al. The impact of distension pressure on acute endothelial cell loss and neointimal proliferation in saphenous vein grafts. Eur J Cardiothorac Surg (2012) 42(4):e74-9. doi:10.1093/ejcts/ezs402

28. Li FD, Sexton KW, Hocking KM, Osgood MJ, Eagle S, Cheung-Flynn J, et al. Intimal thickness associated with endothelial dysfunction in human vein grafts. J Surg Res (2013) 180(1):e55-62. doi:10.1016/j.jss.2012.06.017

29. Okon EB, Millar MJ, Crowley CM, Bashir JG, Cook RC, Hsiang YN, et al. Effect of moderate pressure distention on the human saphenous vein vasomotor function. Ann Thorac Surg (2004) 77(1):108-14; discussion 114-105. doi:10.1016/j.athoracsur.2003.06.007

30. Dhein S, Reiss N, Gerwin R, Borowski A, Korb H, Klaus W, et al. Endothelial function and contractility of human vena saphena magna prepared for aortocoronary bypass grafting. Thorac Cardiovasc Surg (1991) 39(2):66-9. doi:10.1055/s-2007-1013933

31. Soyombo AA, Angelini GD, Bryan AJ, Newby AC. Surgical preparation induces injury and promotes smooth muscle cell proliferation in a culture of human saphenous vein. Cardiovasc Res (1993) 27(11):1961-7. doi:10.1093/cvr/27.11.1961

32. Collins T, Read MA, Neish AS, Whitley MZ, Thanos D, Maniatis T. Transcriptional regulation of endothelial cell adhesion molecules: NF-kappa B and cytokine-inducible enhancers. FASEB J (1995) 9(10):899-909.

33. Frank PG, Lisanti MP. ICAM-1: role in inflammation and in the regulation of vascular permeability. Am J Physiol Heart Circ Physiol (2008) 295(3):H926-7. doi:10.1152/ajpheart.00779.2008

34. Levi M, van der Poll T, Schultz M. Infection and inflammation as risk factors for thrombosis and atherosclerosis. Semin Thromb Hemost (2012) 38(5):506-14. doi:10.1055/s-0032-1305782

35. Chello M, Mastroroberto P, Frati G, Patti G, D’Ambrosio A, Di Sciascio G, et al. Pressure distension stimulates the expression of endothelial adhesion molecules in the human saphenous vein graft. Ann Thorac Surg (2003) 76(2):453-8; discussion 458. doi:10.1016/S0003-4975(03)00433-8

36. Kubes P, Suzuki M, Granger DN. Nitric oxide: an endogenous modulator of leukocyte adhesion. Proc Natl Acad Sci U S A (1991) 88(11):4651-5. doi:10.1073/pnas.88.11.4651
37. Lefer AM, Campbell B, Shin YK, Scalia R, Hayward R, Lefer DJ. Simvastatin preserves the ischemic-reperfused myocardium in normocholesterolemic rat hearts. Circulation (1999) 100(2):178-84. doi:10.1161/01.CIR.100.2.178

38. Jin H, Gebska MA, Blokhin IO, Wilson KM, Ketsawatsomkron P, Chauhan AK, et al. Endothelial PPAR-gamma protects against vascular thrombosis by downregulating P-selectin expression. Arterioscler Thromb Vasc Biol (2015) 35(4):838-44. doi:10.1161/ATVBAHA.115.305378

39. Sumagin R, Lomakina E, Sarelius IH. Leukocyte-endothelial cell interactions are linked to vascular permeability via ICAM-1-mediated signaling. Am J Physiol Heart Circ Physiol (2008) 295(3):H969-77. doi:10.1152/ ajpheart.00400.2008

40. Chai JW, Song Q. Quantitative and multiplexed study of endothelial cell inflammation. Cell Biochem Biophys (2014) 70(3):1783-90. doi:10.1007/ s12013-014-0129-8

41. Lee GL, Chang YW, Wu JY, Wu ML, Wu KK, Yet SF, et al. TLR 2 induces vascular smooth muscle cell migration through cAMP response element-binding protein-mediated interleukin-6 production. Arterioscler Thromb Vasc Biol (2012) 32(11):2751-60. doi:10.1161/Atvbaha.112.300302

42. Rafieian-Kopaei M, Setorki M, Doudi M, Baradaran A, Nasri H. Atherosclerosis: process, indicators, risk factors and new hopes. Int J Prev Med (2014) 5(8):927-46.

43. Saxena A, Rauch U, Berg KE, Andersson L, Hollender L, Carlsson AM, et al. The vascular repair process after injury of the carotid artery is regulated by IL-1RI and MyD88 signalling. Cardiovasc Res (2011) 91(2):350-7. doi:10.1093/cvr/cvr075

44. Borghi MO, Raschi E, Grossi C, Chighizola CB, Meroni PL. Toll-like receptor 4 and beta2 glycoprotein I interaction on endothelial cells. Lupus (2014) 23(12):1302-4. doi:10.1177/0961203314536479

45. Pierangeli SS, Vega-Ostertag ME, Raschi E, Liu X, Romay-Penabad Z, De Micheli V, et al. Toll-like receptor and antiphospholipid mediated thrombosis: in vivo studies. Ann Rheum Dis (2007) 66(10):1327-33. doi:10.1136/ ard.2006.065037

46. Palkama T, Majuri ML, Mattila P, Hurme M, Renkonen R. Regulation of endothelial adhesion molecules by ligands binding to the scavenger receptor Clin Exp Immunol (1993) 92(2):353-60. doi:10.1111/j.1365-2249.1993. tb03404.x

Conflict of Interest Statement: CB has a proprietary interest in VasoPrep Surgical, Inc. EW has no conflicts of interest to disclose.

Copyright (C) 2016 Wise and Brophy. This is an open-access article distributed under the terms of the Creative Commons Attribution License (CC BY). The use, distribution or reproduction in other forums is permitted, provided the original author(s) or licensor are credited and that the original publication in this journal is cited, in accordance with accepted academic practice. No use, distribution or reproduction is permitted which does not comply with these terms. 